\title{
PERBANDINGAN METODE TRANSFORMASI WAVELET DAN FOURIER DALAM PENTERJEMAHAN AYAT PADA SURAH YASIN
}

\author{
${ }^{1}$ Nurdin, ${ }^{2}$ Nadilla Baimal Puteri \\ ${ }^{12}$ Program studi Teknik Informatika, Universitas Malikussaleh \\ Jl. Batam Bukit Indah- Lhokseumawe \\ Email:nurdin@unimal.ac.id, nadillabaimalputeri@gmail.com
}

(Diterima: 21 Agustus 2019, direvisi: 2 November 2019, disetujui: 17 November 2019)

\begin{abstract}
The Qur'an was revealed through the Prophet Muhammad SAW is a guide from Allah for all Muslims. Generally, many people can only read, but they do not understand the content of their reading. Therefore we need a translator system of the Qur'an in the form of audio (sound) to facilitate the reader to understand its contents. This application system used a file format of wave (.wav) for its audio file. In the study of the Surah Yasin, the Verse translation system used a comparison of two methods, namely the Wavelet method and the Fourier method. The stages in this research method were: literature study, collecting surah Yasin samples, system design, system implementation, system testing and comparison of accuracy results between the Wavelet and Fourier transform methods. The output of this study was the translation of the surah Yasin. Both the implementation of the Wavelet and Fourier methods for verse translation in surah Yasin were different. Wavelet detection was $72.9 \%$, while the Fourier was only 43.7\%. These data illustrated that the accuracy of the Wavelet method was better than the Fourier in the translation application system of verse Yasin..
\end{abstract}

Keywords: Wavelet Method, Fourier Method, Yasin, Sound.

\begin{abstract}
ABSTRAK
Kitab Al-qur'an diturunkan melalui Nabi Muhammad SAW merupakan panduan dari Allah bagi seluruh umat Islam. Umumnya banyak orang hanya bisa membaca, belum memahami isi yang terdapat dalam bacaannya, oleh sebab itu diperlukan sistem penerjemah ayat Al-qur'an dalam bentuk audio (suara) untuk memudahkan pembaca memahami kandungan dari ayat itu. Dalam aplikasi sistem ini file suaranya menggunakan format wave (.wav). Pada penelitian sistem terjemahan ayat surah Yasin dengan menggunakan perbandingan dua metode, yaitu metodeWavelet dan metode Fourier. Tahapan yang digunakan padametode penelitian ini yaitu: studi pustaka, mengumpulkan sampel surah yasin, desain sistem, implementasi sistem, testing (pungujian) sistem dan perbandingan hasil akurasi antara merode transformasi Wavelet dan Fourier, denganoutputnya berupa hasil terjemahan surah yasin. Adapun hasil implementasi metode Wavelet transpormation dan Fourier untuk terjemahan ayat pada surah yasin ini mendapatkan hasil nilai yang berbeda. Transformasi Wavelet dengan hasil deteksinya mencapai 72,9 \%, sedangkan metode Fourier mencapai 43,7 \%.Hasil ini menunjukan metode Wavelet akurasinya lebih baik dari metode Fourier dalam aplikasi sistem penterjemahan ayat surah yasin.
\end{abstract}

Kata Kunci: Metode Wavelet, Metode Fourier, Yasin, Suara

\section{PENDAHULUAN}

Kitab Al-qur'an bagian yang tidak terpisahkan dari kehidupan umat Islam sehari-hari. Dengan adanya Al-quran, bagi umat Islam dapat mendapatkan hukum-hukum danpenjelasan tentang suatu gejala sosial dalam bermasyarakat. Allah SWT telah menurunkannya kitab Al-qur'an dalam bahasa Arab didalamnya terdapat 30 juz, 114 surah, 6236 ayat [1].Ayat surah Yasin mempunyai pahala banyak bagi pembacanya serta dapat mendatangkan nilai keberkahan atau kedamaian bagi kehidupan bermasyarakat. Dengan demikian, membaca al-qur'an, diantaranya surah yasin yang merupakan keharusan untuk umat beragama Islam, baik tekstual dan kontekstual [2].

Husain Adz-Dzahabi, menjelaskna terjemahan Al-qur'an merupakan pengalihan ataupun pemindahan dari satu bahasa ke bahasa yang lain tanpa mengurangi makna dan isi dari bahasa asal

Nurdin, Perbandingan Metode Transformasi Wavelet Dan Fourier Dalam Penterjemahan Ayat Pada Surah Yasin 
diterjemahkan ataupun penafsiran pembicaraan dengan penjelasan yang terdapat didalamnya dengan memakai bahasa yang lain. Sehingga secara literatur dapat memuat berbagai metode serta model terjemahan dengan memperhatikannya kesesuaian makna atau sekedar menyalinkan kebentuk bahasa lainnya[3].Teknologi pengolahan citra salah satu model teknologi dalam penyelesaianyang berhubungan dengan masalah pemrosesan gambar maupun suara[6], misalnya pengolahan citra untuk klasifikasi kecantikan wanita [16], sedangkan suara (audio) merupakan sarana utama untuk bisa berkomunikasi antarsesama manusia[4].

Audio adalahsuatu gelombang longitudinalbisa merambat melalui zat perantara atau medium. Zat perantaranyabisa berupa zat cair, padat dan gas. Suara juga dapat disebut kumpulan atau gabungan dari berbagai sinyal getaran terdiri dari gelombang, sedangkan suara yang asli secara teori bisa dijabarkan dengan menggunakan kecepatan getar osilasi ataupun frekuensi yang dapat diukur dengan menggunakan $(\mathrm{Hz})$, sedangkan kenyaringan atau amplitudomerupakan bunyi dengan pengukuran menggunakan $(\mathrm{dB})[7]$.

Transformasi merupakan proses perubahan data ke bentuk yang lain sehingga mudah di analisa. Misalnya, tranformasi Fourier dapat melakukan proses pengubahan sinyal kedalam gelombang kosinus yang berbeda frekuensi. Transformasi Wavelet merupakan suatu proses pengubahan sinyal ke dalam Wavelet basis (mother wavelet). Proses tranformasi Wavelet dilakukan dengan cara konvolusi sinyal dengan data tapis dengan pengurangan dilakukan secara berulang, yang sering disebut metode filter bank [11].

Dalam penelitian yang dilakukan ini penulis melakukan perbandingan metode Wavelet dan Fourier dan melakukan pengujian serta membangun sistem penterjemahan ayat surah Yasin. Alasan memilih metode Wavelet dan Fourier disebabkan karena duametode Transformasi ini mewakili dari transformasi yang ada. Cara kerja metode Wavelet transpormation sinyal yang ada ditransformasikan dengan cara membandingkan nilai dengan sinyal terdekat, untuk metode Fourier transpormation sinyal hanya ditransformasikan dengan menggabungkanfungsi sin dan fungsi $c o s$.

\section{TINJAUAN PUSTAKA}

Ada beberapa penelitian sebelumnya yang mengkaji masalah citra dengan menggunakan metode tranformasi Wavelet yang dilakukan oleh Haris Rangkuti yaitu mangklasifikasi motif batik yang berbasis kemiripan pada ciri dengan transformasi wavelet dan Fuzzy jaringan saraf tiruan, dengan citra atau gambar batik yang diproses ada tujuh model motif batik antara lain motif ceplok, motif kawung, motif lereng, motif parang, motif megamendung, motif tambal dan motif nitik, dari hasil proses pengelompokan citra atau gambar batik baru bisa segera diketahui jenis atau model motif batik dengan hasil tingkat presisi mencapai 86-92\% [12]. Penelitian lain yang dilakukan oleh [13], menjelaskan tranformasi Wavelet sangat baik digunakan sebagai proses awal untuk mengekstraksi ciri citra sidik jari dengan tingkat keberhasilan pengenalan mencapai $90 \%$ dengan waktu proses pengenalan yang pendek yaitu 0.11 detik, dengan ukuran database 1500 record. Penelitian lainnya yang mengkaji masalah tranformasi Fourier yang dilakukan oleh [14], menjelaskan transformasi Fouriermerupakan sebuah tools untuk komputasi dengan sifat simetris antara sinyal dengan frekuensi domain, dengan hasil penelitiannya metode transformasi fourier dengan menggunakan zero frequensi serta amplitudo kecil, diperoleh hasil terhadap panjang transformasi dengan mean 140.93. Penelitian sebelumnya masalah suara dan citra Al-quran, antara lain penelitian dilakukan oleh Nurdin menunjukan bahwa metode Peirce bisa dipakai untuk kalkulasi jarak dari hasil keakuratan pola lafadz Allah dan Muhammad untuk citra Al-qur'an[5].Semakin banyak sampel yang di training dan yang diujikan dapat mempengaruhi keakuratan dari sistem. Hasil penelitian, penerapan huruf pejazam Fi'il Mudhari' untuk citra pada Alqur'an dengan dengan metode Czekanowski [8], akan lebih cepat deteksinya jika gambar hasil scaner tidak pecah. Hasil testing $\mathrm{C} 1$ dan $\mathrm{C} 2$ menunjukan detection rate dipengaruhi oleh nilai vektor tiap pola huruf pejazam fi'il mudhari'.

Berdasarkan hasil dari tinjauan pustaka yang telah dilakukan dari beberapa penelitian sebelumnya, belum membahas masalah perbandingan dari metode Wavelet dan metode Fourier untuk pengolahan citra dalam menterjemahkan ayat Al-qur'an, sehingga penulis tertarik untuk mengembangkan sistem pengolahan citra untuk menterjemahkanayat surah yasin dengan membandingkan kedua metode tersebut untuk mengetahui tingkat keakurasi hasil terjemahan. 


\subsection{Metode Transformasi Wavelet}

Wavelet merupakan suatu gelombang pendek (small wave), Wavelet mengkonversikan sinyal kedalam bentuk sederetan Wavelet. Small wave atau gelombang singkat yaitu suatu fungsi yang berada pada waktu yang berbeda. Metode transformasi Wavelet merupakan perbaikan dari metode transformasi Fourier. Metode Fourier hanya untukpenentuan frekuensi yang ada pada sinyal, dan tidak bisa dalam penentuan kapan dan dimana frekuensi itu ada. Metode transformasi Wavelet dapat memberikan informasi mengenai frekuensi yangada. Wavelet transpormationjuga bisa dipergunakan dalam melakukan analisa bentuk gelombang dari frekuensidan skala[9].Berikut ini rumus Discrete Wavelet Transform (DWT) untuk menghitung nilai rata-rata [15]:

$$
\mathrm{P}=\frac{x+y}{2}
$$

Sedangkan pengurangan dilakukan dengan rumus

$$
\mathrm{P}=\frac{x-y}{2}
$$

\subsection{Metode FourierTransformation}

Metode Fourieradalah model transformasi yang dapat melakukan pemindahansinyal domain spasial menjadi sinyal domain frekuensi. Dalam teknologi pengolahan suara, transformasi ini banyak dipergunakan dalam merubah spasial domain untuk suara menjadi domain frekuensi. Hasil analisa untuk domain frekuensi sering dipergunakan, misanya filtering. Berikut ini rumus metode Fourier yang banyak dipakai pada pengolahan citra digital[10].

$$
F(u)=\frac{1}{N} \sum_{x=0}^{n-1} F(x) \exp \left(\frac{-2 j \pi u x^{2}}{N}\right)
$$

\section{METODE PENELITIAN}

Tahapan atau langkah-langkah yang digunakan pada penelitian sistem penterjemahan ayat pada surah yasin dengan perbandingan metode transformasi Wavelet dan Fourier berikut ini:

a. Studi Kepustakaan

Studikepustakaan diperlukan untuk mempelajari studi literatur dan referensi yang berhubungan dengan penerapan metode yang berkaitan dengan pengolahan citra dan suara, metodeWavelet dan Fourier.

b. Mengumpulkan data

Data yang dipakai pada penelitian berupa sample rekaman bacaan surah yasin ayat 1-12 dalam bentuk format wav.

c. Perancangan Sistem

Mendeskripsikan proses kerja sistem secara rinci dengan menggunakan skema sistem dan flowchart, kemudian mengimplementasikan hasil rancangan yang telah dideskripsikan menjadi sebuah aplikasi.

d. Implementasi Sistem

Tahapan pembuatan aplikasi yang merupakan hasil dari proses analisa dan perancangan dengan menampilkan interface dari aplikasi.

e. Pengujian Sistem

Menampilkanhasil pengukuran keakuratan kerja dari sistem yang telah diimplementasikan dengan melakukan proses training dan testing.

f. Perbandingan Hasil Akurasi

Menampilkan hasil perbandingan akurasi dari kedua metode yang digunakan.

Berikut ini secara ringkas diagram alir dari penelitian: 


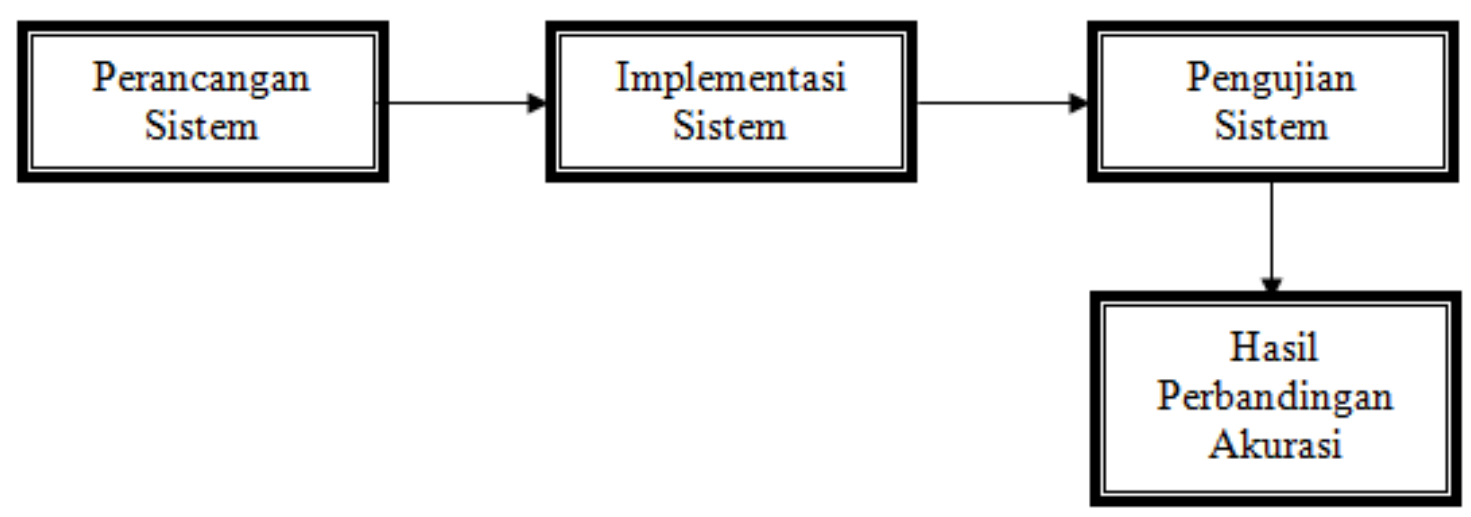

Gambar 1 Metode alur penelitian

\section{HASIL DAN PEMBAHASAN}

\subsection{Perancangan Sistem}

Desain sistem penterjemahan ayat pada surah yasin dengan transformasi Wavelet dan metode Fourier dapatdiilustrasikan berikut ini:

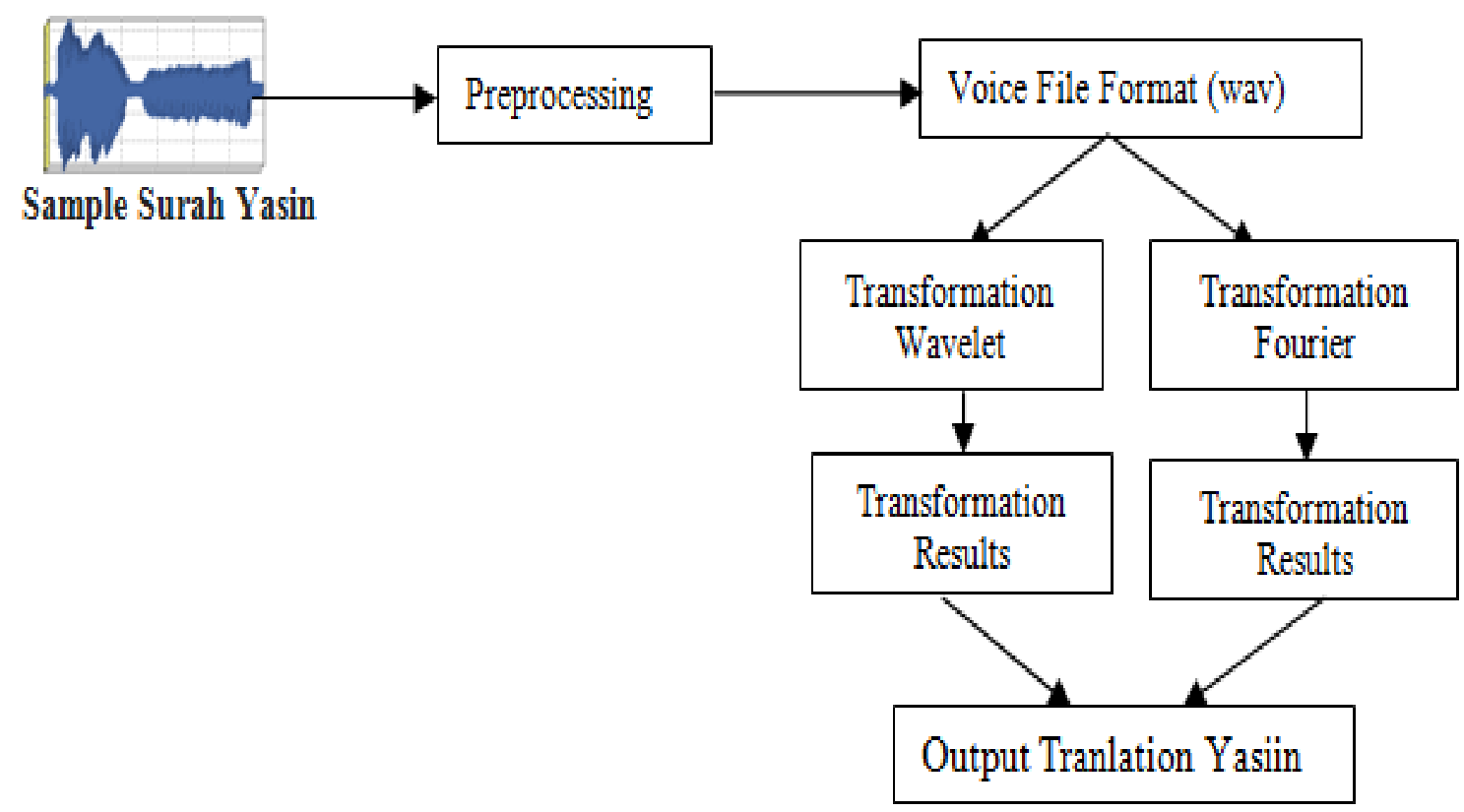

\section{Gambar 2 Perancangan sistem}

Berdasarkan gambar perancangan sistem diatas,langkah awal menginput sample bacaan ayat 1-12 pada surah yasindalam bentuk sampeldata suara rekaman, kemudian sinyal tersebut diproses melalui prepocesing dengan melakukan ekstraksi data dari suara dengan format (.wav). setelah proses selesai akan menampilkan nilai dari picth data suara, nilai picth diinputkan ke sistem dengan menggunakan metode transformasi Wavelet dan Fourier kemudian baru bacaan tersebut berhasil dikenali atau tidak. Langkah selanjutnya sistem menampilkan keluaranhasil terjemahan dalam bahasa indonesia berdasarkan ayat surah yasin. Sistem aplikasi ini dirancang dengan memakai bahasa pemograman Delphi.

\subsection{Perhitungan Dengan Sistem Manual}

\section{a. Perhitungan dengan MetodeWavelet}




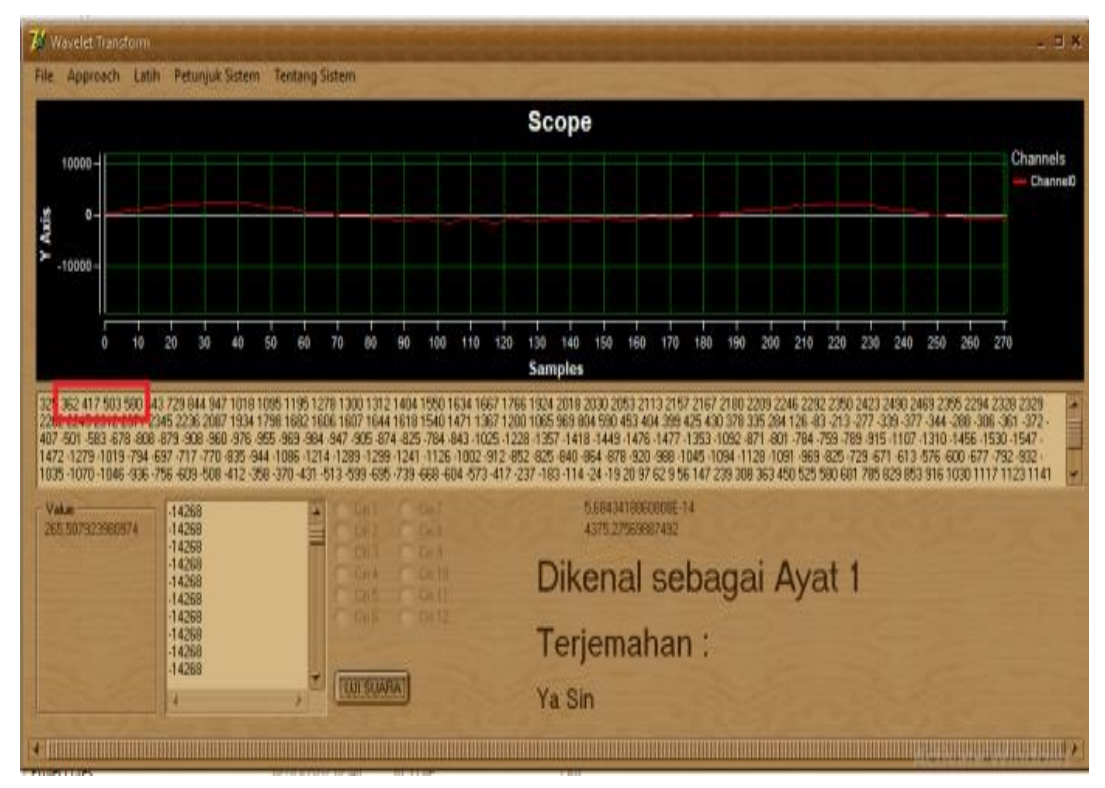

\section{Gambar 3 Nilai pitchdata suara dari metode wavelet}

Perhitungan Manual metode Wavelet berdasarkan pada frekuensi dan waktu untuk surah yasin: Diketahui Sinyal dari Citra suara pada gambar 3, dengan Nilai Pitchnya $=[503,417,580,362]$

$$
\begin{aligned}
& \text { Rumus perataan DWT: } \mathrm{P}=\frac{x+y}{2} \\
& \text { Rumus pengurangan DWT: } \mathrm{P}=\frac{x-y}{2}
\end{aligned}
$$

Nilai sinyal dari citra awal:

\begin{tabular}{|l|l|l|l|}
\hline 503 & 417 & 580 & 362 \\
\hline
\end{tabular}

Hasil perataan pada citra diatas:

$$
\frac{503417}{460} \frac{580362}{471}
$$

Hasil pengurangan pada citra di atas:

$$
\frac{503417}{43} \frac{580362}{109}
$$

Hasil perhitungan manual metode Wavelet dari perataan dan pengurangan pada citra:

\begin{tabular}{|l|c|c|c|}
\hline 460 & 471 & 43 & 109 \\
\hline
\end{tabular}

\section{b. Perhitungan dengan Metode Fourier}




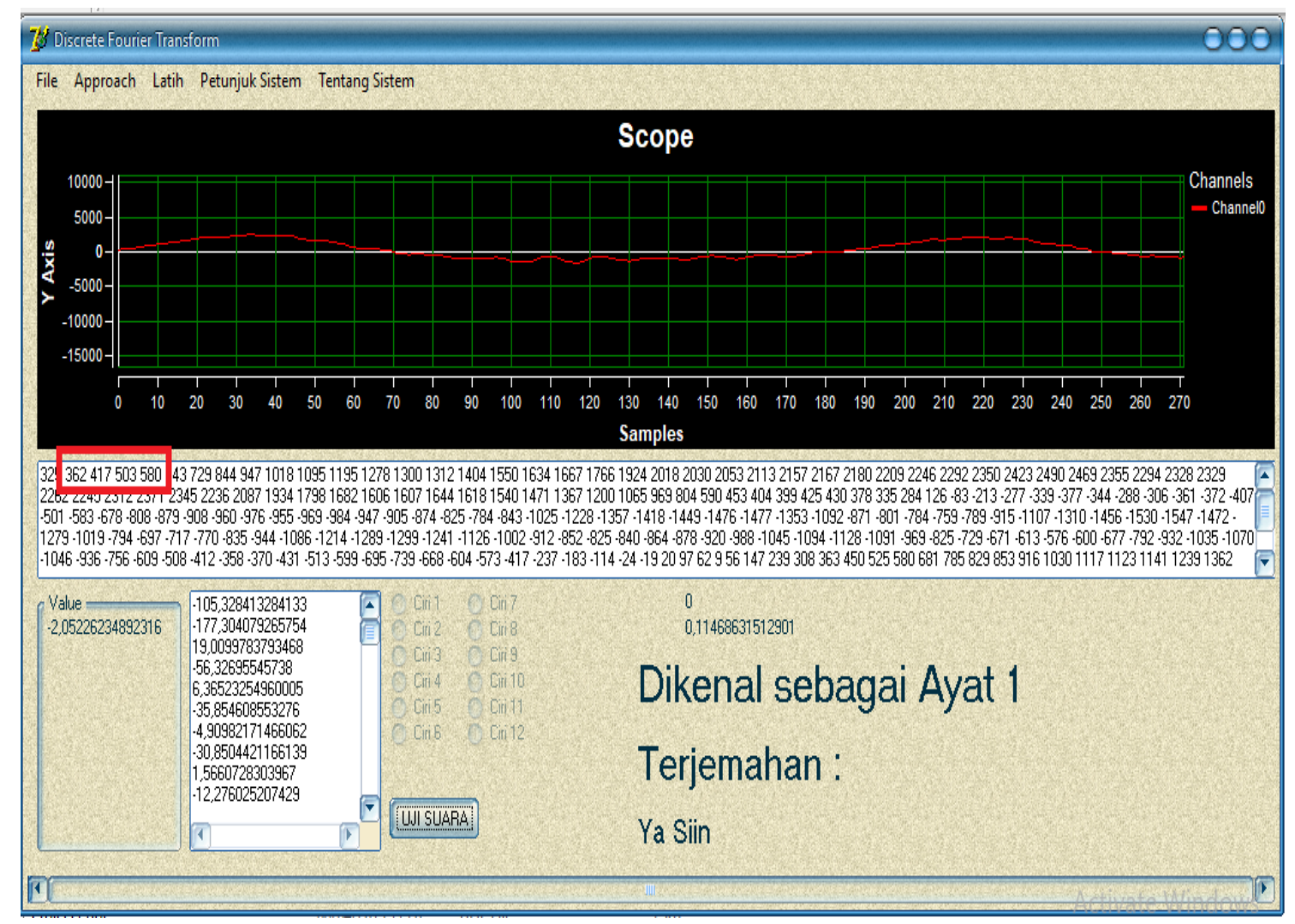

\section{Gambar 4 Nilai pitch data suara dari metode fourier}

Proses menghitung manual metode Fourier berdasarkan pada frekuensi serta waktu untuk surah yasin:

Diketahui sinyal dari citra suara pada gambar 4, dengan Nilai Pitchnyaf $(x)=[503,417,580,362]$

$$
\begin{aligned}
& F(u)=\frac{1}{N} \sum_{x=0}^{n-1} f(x)(\cos (2 \pi u x / N)-j \sin (2 \pi u x / N)) \\
& F(0)=\frac{1}{4}(503) \cos \left(\frac{2 \pi \cdot 0.0}{4}\right)-j \sin \left(\frac{2 \pi \cdot 0.0}{4}\right)+(417) \cos \left(\frac{2 \pi \cdot 0.1}{4}\right)-j \sin \left(\frac{2 \pi \cdot 0.1}{4}\right)+ \\
& (580) \cos \left(\frac{2 \pi \cdot 0.2}{4}\right)-j \sin \left(\frac{2 \pi \cdot 0.2}{4}\right)+(362) \cos \left(\frac{2 \pi \cdot 0.3}{4}\right)-j \sin \left(\frac{2 \pi \cdot 0.3}{4}\right) \\
& =\frac{1}{4}(503+417+580+362) \\
& =\frac{1862}{4}=465.5 \\
& F(1)=\frac{1}{4}(503) \cos \left(\frac{2 \pi \cdot 1.0}{4}\right)-j \sin \left(\frac{2 \pi .1 .0}{4}\right)+(417) \cos \left(\frac{2 \pi \cdot 1.1}{4}\right)-j \sin \left(\frac{2 \pi \cdot 1.1}{4}\right)+ \\
& (580) \cos \left(\frac{2 \pi \cdot 1.2}{4}\right)-j \sin \left(\frac{2 \pi \cdot 1.2}{4}\right)+(362) \cos \left(\frac{2 \pi \cdot 1.3}{4}\right)-j \sin \left(\frac{2 \pi \cdot 1.3}{4}\right) \\
& =\frac{1}{4} 503(1-0)+417(0-\mathrm{J})+580(-1-0)+362(0+\mathrm{J}) \\
& =\frac{1}{4}(503-417 \mathrm{~J}-580+362 \mathrm{~J}) \\
& =\frac{1}{4}(-77+(-55 \mathrm{~J})) \\
& =-19,25-13,75 \mathrm{~J} \\
& F(2)=\frac{1}{4}(503) \cos \left(\frac{2 \pi \cdot 2.0}{4}\right)-j \sin \left(\frac{2 \pi \cdot 2.0}{4}\right)+(417) \cos \left(\frac{2 \pi \cdot 2.1}{4}\right)-j \sin \left(\frac{2 \pi \cdot 2.1}{4}\right)+ \\
& (580) \cos \left(\frac{2 \pi \cdot 2.2}{4}\right)-j \sin \left(\frac{2 \pi \cdot 2.2}{4}\right)+(362) \cos \left(\frac{2 \pi \cdot 2.3}{4}\right)-j \sin \left(\frac{2 \pi \cdot 2.3}{4}\right)
\end{aligned}
$$




$$
\begin{aligned}
= & \frac{1}{4} 503(1-0)+417(-1-0)+580(1-0)+362(-1-0) \\
= & \frac{1}{4}(503-417-580+362) \\
= & \frac{1}{4}(304)=\frac{304}{4}=76 \\
F(3)= & \frac{1}{4}(503) \cos \left(\frac{2 \pi \cdot 3 \cdot 0}{4}\right)-j \sin \left(\frac{2 \pi \cdot 3.0}{4}\right)+(417) \cos \left(\frac{2 \pi \cdot 3 \cdot 1}{4}\right)-j \sin \left(\frac{2 \pi \cdot 3.1}{4}\right)+ \\
& \quad(580) \cos \left(\frac{2 \pi \cdot 3.2}{4}\right)-j \sin \left(\frac{2 \pi \cdot 3 \cdot 2}{4}\right)+(362) \cos \left(\frac{2 \pi \cdot 3 \cdot 3}{4}\right)-j \sin \left(\frac{2 \pi \cdot 3 \cdot 3}{4}\right) \\
= & \frac{1}{4} 503(1-0)+417(0+1 \mathrm{~J})+580(-1-0)+362(0-1 \mathrm{~J}) \\
= & \frac{1}{4}(503+417 \mathrm{~J}+(-580)-362 \mathrm{~J}) \\
= & \frac{1}{4}(-77+55 \mathrm{~J}) \\
= & -19,25+13,75 \mathrm{~J}
\end{aligned}
$$

Karena ada bilangan imaginer dari proses perhitungan, sehingga hasilnya perlu dispectrumkan untuk mendapatkan nilai real dengan menggunakan cara :

$$
\begin{aligned}
|\mathrm{F}(u)| & =\left(R(u)^{2}+I(u)^{2}\right)^{1 / 2} \\
|\mathrm{~F}(0)| & =\left[\left(465.5^{2}+0^{2}\right)\right]^{1 / 2} \\
& =(216.690 .25+0)^{1 / 2} \\
& =\sqrt{216.690,25} \\
& =465.5 \\
|\mathrm{~F}(1)| & =\left[(-19,25)^{2}+(13,75)^{2}\right]^{1 / 2} \\
& =(370.5652+189.0625)^{1 / 2} \\
& =\sqrt{559,625} \\
& =23.656 \\
|\mathrm{~F}(2)| & =\left[(76)^{2}+0^{2}\right]^{1 / 2} \\
& =(5.776+0)^{1 / 2} \\
& =\sqrt{5.776} \\
& =76 \\
|\mathrm{~F}(3)| & =\left[(-19,25)^{2}+(13,75)^{2}\right]^{1 / 2} \\
& =(370.5652+189.0625)^{1 / 2} \\
& =\sqrt{559,625} \\
& =23.656
\end{aligned}
$$

Hasil perhitungan manual metode Fourier pada citra $\mathrm{f}(\mathrm{x})$ menjadi :

$[465.5,23.656,76,23.656]$ 


\subsection{Implementasi Sistem}

Tahapan implementasi pada sistem ini, pengguna memasukan sampel data suara surah yasin yang berformat (.wav) yang telah dipisahkan untuk proses pengujian menggunakan button pengujian suara, sehingga sistem akan mengenali suara dari ayat surah yasin, benar atau salah dan hasilnya ditampilkan pada sistem.

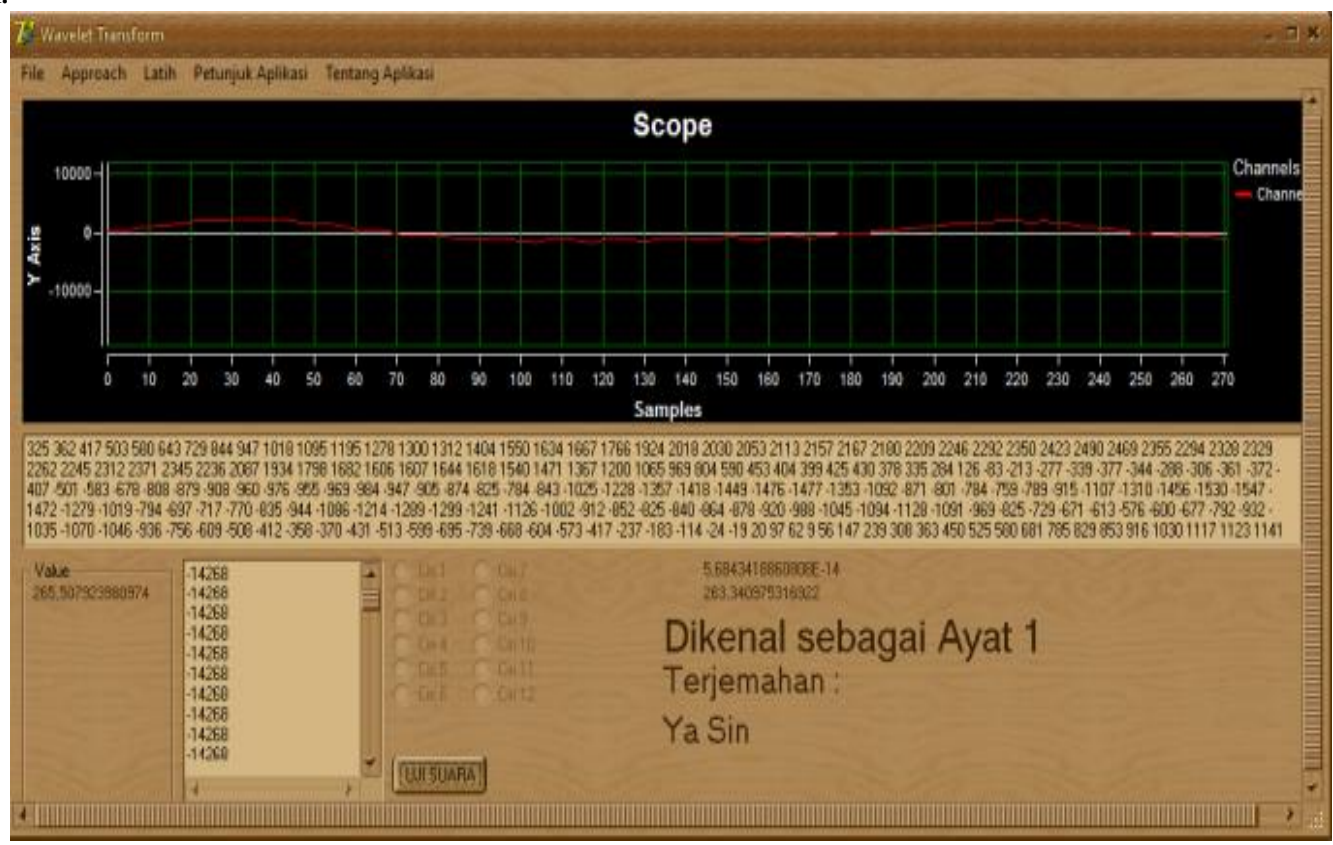

Gambar 5 Tampilan form testing pada metode wavelet

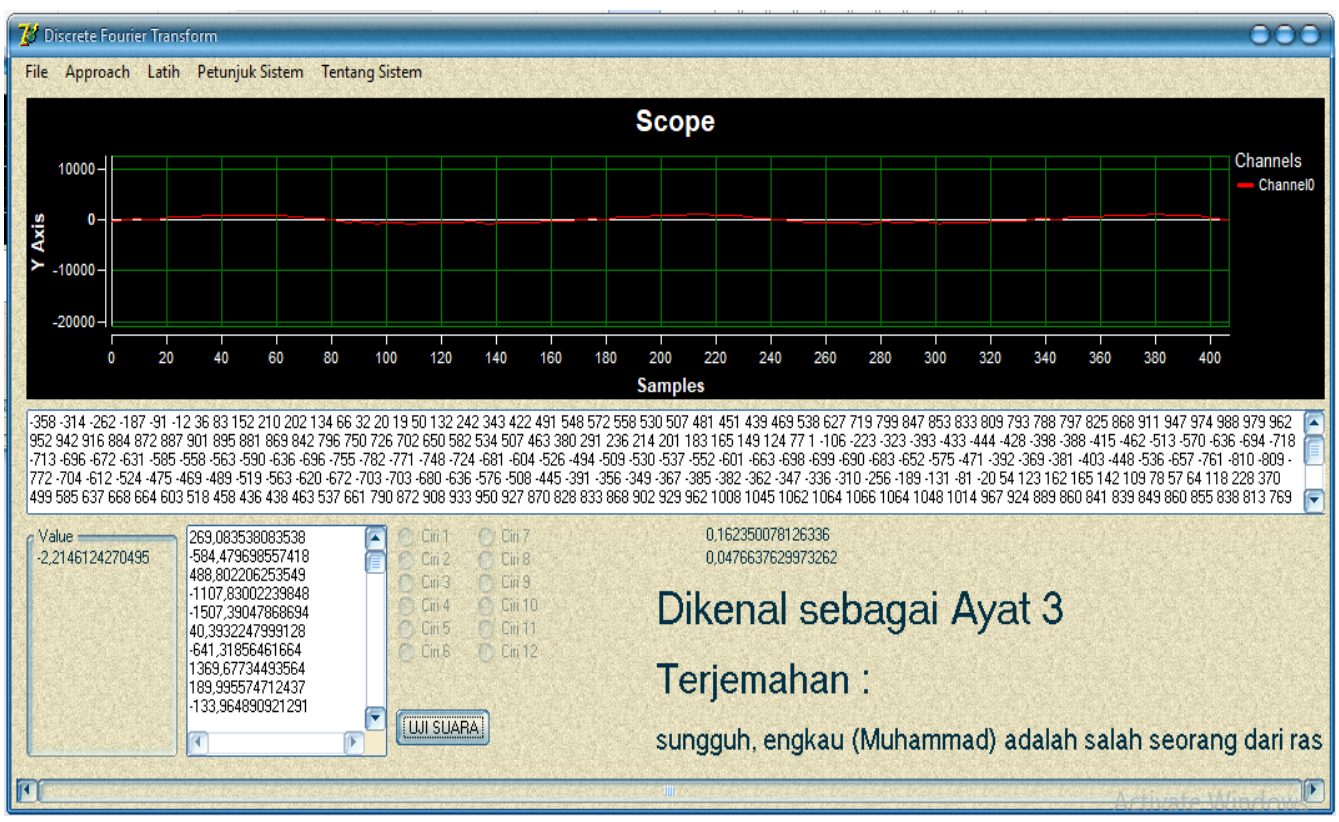

Gambar 6 Tampilan formtestingpada metode fourier

\subsection{Pengujian Sistem}

Pengujian sistem adalah hasil pengukuran keakuratan kerja dari sistem aplikasi penterjemah ayat dari surah yasin melalui suara dengan menggunakan metode transformasi Wavelet dan metode Fourier dengan cara melakukan proses pengujian untuk sampel suara yang sudah dilakukan proses pelatihan maupun yang belum dilakukan pelatihan, sehingga dapat diketahui hasil deteksinya. 
Tabel 1 Hasil pengujian dengan metode wavalet

\begin{tabular}{ccccccc}
\hline Surah Yasin & $\begin{array}{c}\text { Data } \\
\text { Pelatihan }\end{array}$ & $\begin{array}{c}\text { Data } \\
\text { Pengujian }\end{array}$ & Benar & Salah & $\begin{array}{c}\text { Hasil } \\
\text { Deteksi }\end{array}$ & Persentase \\
\hline Yasin (Ayat1) & 5 & 4 & 3 & 1 & 3 & $75 \%$ \\
Yasin (Ayat2) & 5 & 4 & 4 & 0 & 4 & $100 \%$ \\
Yasin (Ayat3) & 5 & 4 & 4 & 0 & 4 & $100 \%$ \\
Yasin (Ayat4) & 5 & 4 & 3 & 1 & 3 & $75 \%$ \\
Yasin (Ayat5) & 5 & 4 & 3 & 1 & 3 & $75 \%$ \\
Yasin (Ayat6) & 5 & 4 & 2 & 2 & 2 & $50 \%$ \\
Yasin (Ayat7) & 5 & 4 & 2 & 2 & 2 & $50 \%$ \\
Yasin (Ayat8) & 5 & 4 & 3 & 1 & 3 & $75 \%$ \\
Yasin (Ayat9) & 5 & 4 & 3 & 1 & 3 & $75 \%$ \\
Yasin (Ayat10) & 5 & 4 & 2 & 2 & 2 & $50 \%$ \\
Yasin (Ayat11) & 5 & 4 & 4 & 0 & 4 & $100 \%$ \\
Yasin (Ayat12) & 5 & 4 & 4 & 2 & 2 & $50 \%$ \\
\hline
\end{tabular}

Nilai rata-rata hasil pengujian

$\mathbf{7 2 , 9 \%}$

Tabel 2 Hasil Pengujian Dengan Metode Fourier

\begin{tabular}{ccccccc}
\hline Surah Yasin & $\begin{array}{c}\text { Data } \\
\text { Pelatihan }\end{array}$ & $\begin{array}{c}\text { Data } \\
\text { Pengujian }\end{array}$ & Benar & Salah & $\begin{array}{c}\text { Hasil } \\
\text { Deteksi }\end{array}$ & Persentase \\
\hline Yasin (Ayat1) & 5 & 4 & 2 & 2 & 2 & $50 \%$ \\
Yasin (Ayat2) & 5 & 4 & 2 & 2 & 2 & $50 \%$ \\
Yasin (Ayat 3) & 5 & 4 & 3 & 1 & 3 & $75 \%$ \\
Yasin (Ayat4) & 5 & 4 & 2 & 2 & 2 & $50 \%$ \\
Yasin (Ayat5) & 5 & 4 & 2 & 2 & 2 & $50 \%$ \\
Yasin (Ayat6) & 5 & 4 & 2 & 2 & 2 & $50 \%$ \\
Yasin (Ayat7) & 5 & 4 & 1 & 3 & 1 & $25 \%$ \\
Yasin (Ayat8) & 5 & 4 & 2 & 2 & 2 & $50 \%$ \\
Yasin (Ayat9) & 5 & 4 & 1 & 3 & 1 & $25 \%$ \\
Yasin (Ayat10) & 5 & 4 & 1 & 3 & 1 & $25 \%$ \\
Yasin (Ayat11) & 5 & 4 & 2 & 2 & 2 & $50 \%$ \\
Yasin (Ayat12) & 5 & 4 & 1 & 3 & 1 & $25 \%$ \\
\hline
\end{tabular}

Nilai rata-rata hasil pengujian

43.7\%

Hasil pengujian pada kedua tabel diatas, menjelaskan bahwa hasil dari deteksi pada setiap ayat surah yasin dipengaruhi oleh jumlah sampel suara training. Nilai persentase diperoleh berdasarkan jumlah hasil deteksi dibagikan dengan jumlah suara pengujian dan dikali 100. Hasil testing (pengujian) dengan metode Wavelet mencapai $72,9 \%$, sedangkan hasil pengujian dengan menggunakan metode Fourier sebesar $43,7 \%$. 


\subsection{Perbandingan Hasil Akurasi}

Berikut ini menampilkan grafik perbandingan hasil akurasi pada tahapan pelatihan dan pengujian sistem. Untuk metode tranformasi Wavelet dengan tingkat hasil deteksi untuk pengujian pada surah, yasin $($ yasin ayat 1$)=75 \%,($ yasin ayat 2$)=100 \%,($ yasin ayat 3$)=100 \%,($ yasin ayat 4$)=75 \%,($ yasin ayat 5$)=75 \%,($ yasin ayat 6$)=50 \%,($ yasin ayat 7$)=50 \%,($ yasin ayat 8$)=75 \%,($ yasin ayat 9$)=75 \%,($ yasin ayat 10$)=50 \%$, (yasin ayat 11$)=100 \%$, dan $($ yasin ayat 12$)=50 \%$, sedangkan hasil metode transformasi Fourier dengan hasil deteksi untuk pengujianpada surah yasin, (yasin ayat 1$)=50 \%$, (yasin ayat 2$)=50 \%$, $($ yasin ayat 3$)=75 \%$, (yasin ayat 4$)=50 \%$, (yasin ayat 5$)=50 \%,($ yasin ayat 6$)=50 \%$, yasin ayat 7$)=$ $25 \%$, $($ yasin ayat 8$)=50 \%$, (yasin ayat 9$)=25 \%$, (yasin ayat 10$)=25 \%,($ yasin ayat 11$)=50 \%$ dan $($ yasin ayat 12$)=25 \%$.

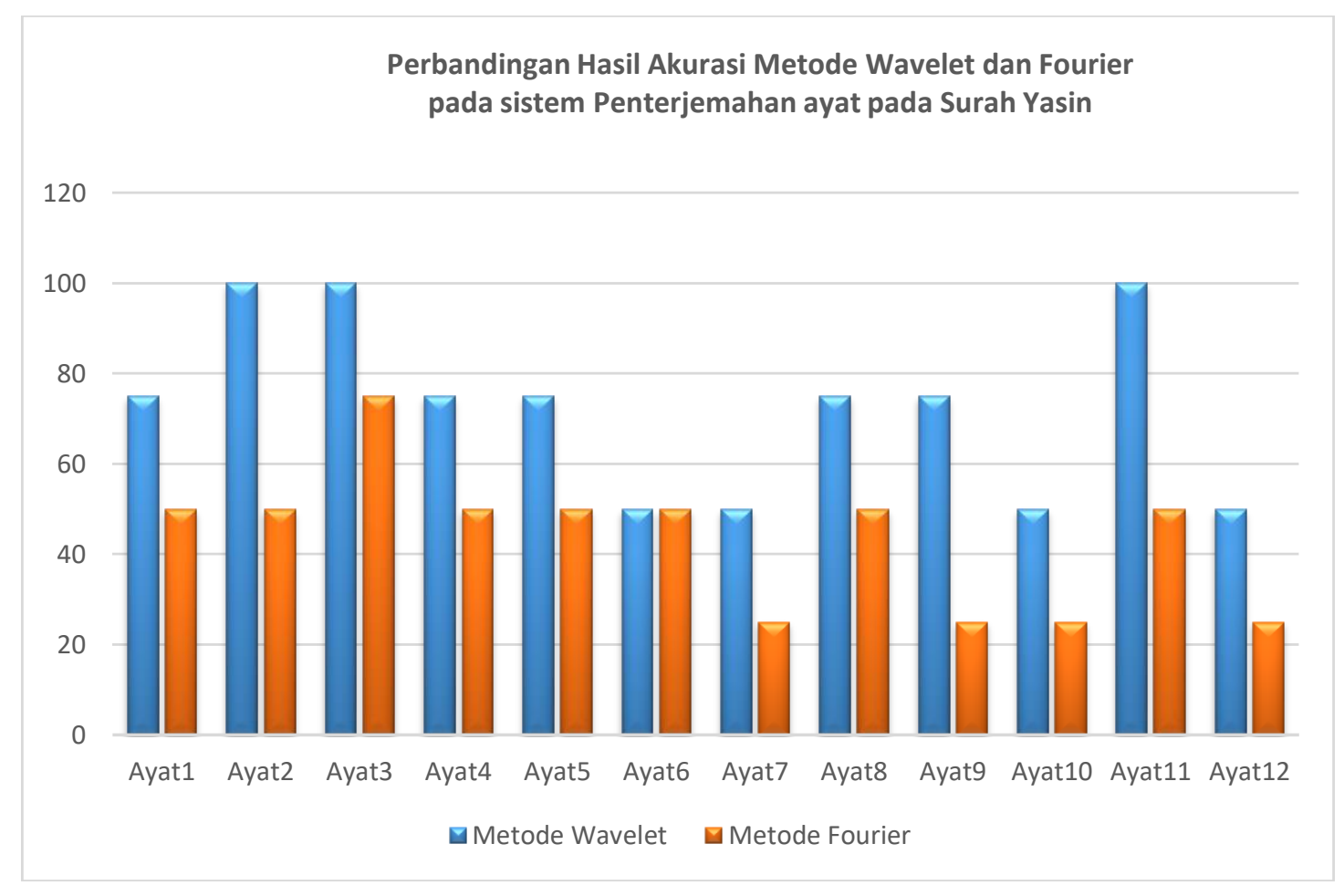

Gambar 7 Grafik perbandingan hasil akurasi

\section{KESIMPULAN}

Hasil dari penelitian sistem pengenalan terjemahan ayat pada surat yasin mendapatkan persentase keakuratan hasil yang berbeda,salah satu penyebabnya karena sistem dalam mentransformasikan sinyal itu berbeda. Pada transformasi Wavelet sinyal dibandingkan dengan sinyal yang terdekat, pada metode transformasi Fourier sinyal itu di transformasi dengan menggabungkanfungsi sin dan fungsi cos. Jumlah sampel pelatihan dan pengujian juga akan mempengaruhi hasil pendeteksian. Dalam sistem aplikasi ini telah dilakukan proses training dan testing dengan metode Wavelet dan metode Fourier. Hasil pengujian menggunakan metode Wavelet dengan hasil deteksi yang benar mencapai 72,9 \%, sedangkan hasil pengujian menggunakan metode Fourier dengan hasil deteksi yang benar mencapai 43,7\%. Hasil perbandingan kedua metode tersebut dapat disimpulkan bahwa metode Wavelet lebih baik dalam sistem pendeteksian penterjemahan ayat pada surah yasin.

\section{REFERENSI}

[1] M. A. Effindi, "Pengembangan Perangkat Lunak Pencarian Ayat Al-Qur'an", Jurnal Ilmiah Edutic, vol.3, No.2, pp. 112-116, 2017.

[2] Hayat, "Pengajian Yasinan Sebagai Strategi Dakwah Dalam Membangun Mental dan Karakter Masyarakat",Jurnal WALISONGO, vol.22, no.2, pp. 297-320, 2014. 
[3] R. Ahmadi, "Model Terjemahan Al-Qur'an Tafsiriyah Ustad Muhammad Thalib",Jurnal CMES, vol. 8, no. 1, pp. 57-69, 2015.

[4] M.A. Anusuya, S.K.Katti, "Speech Recognition By Machine: A Review", International Journal Of Computer Science AndInformation Security (IJCSIS), vol. 6, no. 3, pp. 181-205, 2009.

[5] Nurdin,D. Hamdana and M.J. Setiawan, "Sistem Pendekteksian Pola Lafadz Allah dan Muhammad Pada Citra Al-Qur'an Menggunakan Metode Peirce”, Jurnal TECHSI,vol. 9, no. 2, pp. 78-90, 2017.

[6] F. Muwardi, A.Fadlil, "Sistem Pengenalan Bunga Berbasis Pengolahan Citra dan Pengklasifikasi Jarak", Jurnal JITEKI, vol. 3, no. 2, pp. 124-131, 2017.

[7] E. Setyaningsih, M. A. Novianta "Analisa Perekaman data suara dari sistem Blackbox pada kereta Api”, Jurnal Informatika, vol. 9, no. 1, pp. 993-998, 2015.

[8] Nurdin,U. Fitriani, 'Implementasi Huruf Pejazam Fi'il Mudhari' pada citra Al-Qur'an menggunakan metode Czekanowski", Jurnal TECHSI, vol. 11, no. 1, pp. 61-75, 2019.

[9] A. R. Hakim, "Analisis Perbandingan Discrete Wavelet Transform Discrete Cosine Transform dan Fourier Transform pada proses Pengenalan Pola Suara”, Tesis Magister Teknik Informatika, Universitas Sumatera Utara, 2016.

[10] Fadlisyah,Nurdin and I. Nuriani, "Sistem Pengujian Hafalan Al-Qur'an studi kasus Surah AlAnfaal ayat 1-11 melalui suaramenggunakan metode Transformasi Fourier Diskrit dan Transformasi Sinus Diskrit”, Jurnal TECHSI, vol.10, no.1, pp. 91-107, 2018.

[11] Stollnitz, J. Eric, DeRose, D. Tony and H. Salesin, "Wavelet for computer Graphics: Theory and Application", Morgan Kaufmann Publishers, Inc, 1999.

[12] A.H. Rangkuti, "Klasifikasi motif batik berbasis kemiripan ciri dengan Wavelet Transform dan Fuzzy Neural Nework", Jurnal ComTech, vol. 5, no.1, pp. 361-372, 2014.

[13] I.G.P. Wijaya, B. Kanata, "Pengenalan citra sidik jari berbasis tranformasi Wavelet dan jaringan saraf tiruan", Jurnal Teknik Elektro, vol.4, no.1, pp. 46-52, 2004.

[14]M. Anike, "Analisa Pengolahan Citra Menggunakan metode Transformasi Fourier", Konferensi Nasional Sistem dan Informatika, 2015.

[15]Rizal, L. Rosnita and Ikramina, "Sistem Pengenalan nagham Adzan melalui suara menggunakan metode Discrete Wavelet Transform dan Mellin Transform", Jurnal TECHSI, vol. 10, no. 2, pp. 50-64, 2018.

[16] Nurdin, K. Pratama, "Klasifikasi Kecantikan Wanita Aceh Pada Citra Menggunakan Metode Adaptive Resonance Theory (ART1)", Jurnal TECHSI, vol. 8, no. 1, pp.139-147, 2016. 